\title{
Association study of gene polymorphisms and depression with abnormal humor in traditional Uighur medicine
}

\author{
Abdiryim Yusup ${ }^{\dagger}$, Hanzohra Upur, Ayimgul Abla and Halmurat Upur ${ }^{*+}$
}

\begin{abstract}
Background: According to the humor theory of Traditional Uighur Medicine (TUM), a same disease is classified into different abnormal humor types and corresponding methods are applied to treat the diseases according to the type of abnormal humor characteristics. To date the biological foundation of classification of diseases by humor theory has been little studied and the mechanism of action is still unclear. In the present study, we aimed to investigate the association between some related gene polymorphisms and depression with abnormal humor in TUM.
\end{abstract}

Methods: 201 cases of depression patients in a Uighur population were divided into two groups as: 107 cases of depression patients with abnormal black bile (ABB), 94 cases of depression patients with none abnormal black bile (nABB), and 50 healthy people were served as control group. Venous blood was used to isolate DNA samples, and the polymerase chain reaction-restriction fragment length polymorphism (PCR-RFLP) technique was used for genotyping of single nucleotide polymorphisms (SNPs). Polymorphisms in the serotonin $2 \mathrm{~A}\left(5-\mathrm{HT}_{2 \mathrm{~A}}\right)$ receptor gene, brain derived neurotrophic factor $(B D N F)$, serotonin $1 \mathrm{~A}\left(5-\mathrm{HT}_{1 \mathrm{~A}}\right)$ receptor gene were investigated in each groups, respectively.

Results: The 5-HT $2 \mathrm{~A}$ A-1438G, 5-HT $2 \mathrm{~A}$ T102C, BDNF Val66Met, and 5-HT $1 \mathrm{~A}$ C-1019G gene polymorphisms showed significant association with ABB. However, no difference between $\mathrm{nABB}$ and controls was found for those genotype distribution and allele frequency. Moreover, the T102C and A1438G SNPs in the 5-HT $2 \mathrm{~A}$ receptor gene polymorphisms were in linkage disequilibrium. In addition, the OR associated with the combination of Val66Met-Val/Nal genotype plus the presence of $-1019 \mathrm{C}$ allele was 8.393 for ABB compared with controls (OR 8.393; 95\% Cl 1.807 38.991; $P=0.003$ ). Moreover, the OR associated with the presence of -Met plus -1019C alleles was 12.194 for ABB compared with controls (OR 12.194; 95\% Cl 1.433 103.776; $P=0.005$ ). The OR associated with the presence of $-1438 C / C$ plus Val $N$ al genotypes was 7.738 for $A B B$ compared with controls (OR 7.738; 95\% CI 1.566 38.241; $P=0.005$ ).

Conclusion: It was concluded that there were significant relationship between the gene polymorphisms and classification of depression with abnormal humor in TUM. The 5-HT $2 \mathrm{~A} A-1438 \mathrm{G}, 5-\mathrm{HT}_{2 \mathrm{~A}} \mathrm{T102C}, \mathrm{BDNF}$ Val66Met, and $5-\mathrm{HT}_{1 \mathrm{~A}} \mathrm{C}-1019 \mathrm{G}$ gene polymorphisms might predict the incidence of depression with $\mathrm{ABB}$.

Keywords: Traditional Uighur medicine, Depression, $5-\mathrm{HT}_{2 \mathrm{~A}}, \mathrm{BDNF}, 5-\mathrm{HT}_{1 \mathrm{~A}}$

\footnotetext{
* Correspondence: halmurat@263.net

${ }^{\dagger}$ Equal contributors

Collage of Traditional Uighur Medicine, Xinjiang Medical University, Xinyi

Road 393, Urumqi, China
} 


\section{Background}

Depression is a major public health problem. It tends to have a chronic course, produces disability and is associated with suicide $[1,2]$. There are overwhelming justifications to explore the molecular mechanisms underlying major depressive disorder [3], depression significantly complicates chronic illness [4] and depression is the leading cause of disability worldwide [5].

The disease of depression or melancholy (black bile in Greek) was linked to the Hippocratic/Galenic medical theory of the four humors. Humoral Theory was initially Greek philosophy and firstly brought to medicine by Hippocrates (c.460-370 B.C.), adopted and developed by Greek (e.g. Galen, c.129-216 A.D.), Roman and Islamic physicians (e.g. Avicenna, c.980-1037 A.D.), it became the most commonly held view of the human body among European physicians until the discoveries of the functions of the circulatory, respiratory and digestive systems in 18th century. Essentially, this theory holds that human body was filled with four basic substances or humors- blood, phlegm, yellow bile and black bile. According to Hippocrates Medicine, the four humors needed to be balanced for good health, and an excess or deficit of one of these humors would disrupt the balance of these humors and cause disease [6]. "Abnormal black bile" is the term for an excess of black bile (literally "savda" in Arabic) and Melancholia or Depression was thought to be caused by "Abnormal black bile" by Galen which was adopted by Avicenna [7,8]. Although existence of black bile or abnormal black bile in body has never been confirmed in modern research, the demonstrated symptoms and signs of abnormal black bile were described in detail in Cannon of Medicine by Avicenna [9]. Although the four humors theory was dismantled from $19^{\text {th }}$ century, the definitive methods of Hippocratic medicine clinical diagnostics of abnormal humors have survived intact in the medical system of Uighur people in China. Traditional Uighur Medicine (TUM) considers the unbalanced humors or abnormal changes of humors are thought to cause disorders or diseases, and most clinical works identified the cause of complex diseases such as cancer, depression as an excess of black bile [10-12]., and some researches even indicate patients with "abnormal black bile" were significantly different from those with "non-abnormal black bile" (abnormal blood, yellow bile and phlegm) in terms of gene polymorphism, pre-thrombotic state and oxidative stress [13-15]. However, is "abnormal black bile" an existing phenomenon with distinct biological basis or merely imaginary philosophical concept that causes Depression? We undertook this investigation to answer this question.

The $5-\mathrm{HT}_{2 \mathrm{~A}}$ receptor is widely distributed in the central nervous system and periphery, and associated with major depressive illness [16]. Two single nucleotide polymorphisms, A-1438G and T102C are common in the population, show strong linkage disequilibrium with depression, and are associated with efficacy and positive side effect profiles of anti-depressant medications in some studies [17-20]. The $5-\mathrm{HT}_{1 \mathrm{~A}}$ receptor is a key mediator of serotonergic signaling in the central nervous system, and known as the major autoreceptor of serotonergic raphe neurons [21]. The C-1019G polymorphism of the $5-\mathrm{HT}_{1 \mathrm{~A}}$ gene promoter polymorphism affects 5$\mathrm{HT}_{1 \mathrm{~A}}$ receptor binding potential and protein expression [22]. Several studies suggest that GG genotype or G allele carriers of the $5-\mathrm{HT}_{1 \mathrm{~A}}$ gene promoter polymorphism have a greater risk of depression and poorer response to antidepressant therapy $[18,22]$. Brain-derived neurotrophic factor (BDNF) plays a critical role in neuronal growth, survival and differentiation neuronal cells of the central nervous system [23]. There is increasing evidence that the BDNF might be one of the relevant factors in the pathophysiology of depression [24]. Evidence of an association between the BDNF Val66Met polymorphism and depression is rapidly being replicated [25].

In the present study, we investigated the $5-\mathrm{HT}_{2 \mathrm{~A}}$ T102C, 5- $\mathrm{HT}_{2 \mathrm{~A}} \mathrm{~A}-1438 \mathrm{G}, \mathrm{BDNF}$ Val66Met and 5- $\mathrm{HT}_{1 \mathrm{~A}}$ C-1019G gene polymorphisms in depression patients with two type of abnormal humor in TUM. Some of these gene polymorphisms have been thoroughly studied, but to our knowledge this is the first study to investigate the association of multiple polymorphisms and depression with abnormal humor in TUM. Our purpose was to investigate the association between some related gene polymorphisms and depression with abnormal humor, and whether certain genetic polymorphisms may be predictive markers of depression in patients with abnormal humor in TUM.

\section{Methods \\ Patients and controls \\ Case selection}

Patients including in this study met standards both of Western medicine and Traditional Uighur medicine. Specially, we followed the following criteria: (a) Uighur ethnic group, (b) aged 14 to 80 years, (c) meet the Mood disorder standard of Chinese Classification of Mental Disorders (CCMD-3), (d) the Hamilton Rating Scale for Depression (HAMD) 24-item version scale score $\geq 18$, (e) patients or their parents gave informed consent for this study, and (f) there were no restrictions on gender.

We excluded patients: (a) with cerebrovascular disease or other serious organic brain diseases, (b) with high blood pressure, diabetes and other serious physical illness, (c) with other mental disorders associated with depression, (d) who has a history of manic episodes or anti-depressant induced mania, (e) who recently (within six weeks) received anti-depressant treatment. 


\section{Participates}

We selected 201 patients of Uighur population who were diagnosed by two independent psychiatrists respectively (134 females and 67 males mean age $42.57 \pm 15.64$ years). While 50 healthy volunteers were used as controls (20 females and 30 males with a mean age of $28 \pm 8.56$ years). The research protocol was approved by the First Affiliated Hospital (First Affiliated Hospital, Xinjiang Medical University, Urumqi, China) ethics review committee. Written informed consent was obtained from each subject prior to the study.

\section{Classification of depression by TUM}

201 cases of depression patients were classified into abnormal black bile (ABB) group and none abnormal black bile (nABB) group according to humor classification criteria described in TUM $[9,10]$. The ABB group consisted of 72 females and 35 males with a mean age of $44.19 \pm 15.43$ years and with a mean HAMD score of $37.92 \pm 11.53$. The $\mathrm{nABB}$ group consisted of 62 females and 32 males with a mean age of $40.65 \pm 16.68$ years and with a mean HAMD score of $38.42 \pm 13.59$.

\section{DNA analysis and genotyping DNA preparation}

After 12 hours of fasting, $4 \mathrm{ml}$ of venous blood was collected from each subject in $0.019 \mathrm{~mol} / \mathrm{L}$ sodium citrate (1 portion anticoagulant +9 portion whole blood). DNA was extracted from blood leukocytes with the TIANamp Blood DNA Kit (TIANGEN BIOTECH, Beijing).

\section{5- $H T_{2 A}$ genotyping}

To genotype the A-1438G SNP in the $5-\mathrm{HT}_{2 \mathrm{~A}}$ gene, PCR was performed with the forward primer $5^{\prime}$ CTAGCCACCCTGAGCCTATG-3' and the reverse primer 5' -TTGTGCAGATTCCCATTAAGG-3'. The amplification mixture contained $2 \mu \mathrm{l}$ of $100 \mathrm{ng} / \mu \mathrm{l}$ DNA, $10 \mu$ of $2 \times$ Master Mix $(2 \times$ Taq PCR Master Mix, TIANGEN), $0.5 \mu \mathrm{l}$ of $20 \mu \mathrm{M}$ each primer, $7 \mu \mathrm{l}$ of distilled water in a final volume of $20 \mu \mathrm{l}$. The amplification cycle was performed on a $\mathrm{C} 1000^{\mathrm{m}}$ Thermal Cycler (BIO-RAD, USA). After an initial denaturation at $94^{\circ} \mathrm{C}$ for $3 \mathrm{~min}$, the DNA was amplified by 35 PCR cycles: denaturation at $94^{\circ} \mathrm{C}$ for $30 \mathrm{~s}$, annealing at $58.1^{\circ} \mathrm{C}$ for $30 \mathrm{~s}$ and extension at $72^{\circ} \mathrm{C}$ for $1 \mathrm{~min}$, followed by a final extension at $72^{\circ} \mathrm{C}$ for $7 \mathrm{~min}$, and the reaction was terminated at $4^{\circ} \mathrm{C}$. Amplified products were separated by electrophoresis on $1.5 \%$ agarose gel and visualized with ultraviolet light after ethidium bromide staining. The $2 \times$ Master Mix contained $10 \mathrm{mM}$ Tris-HCl (PH8.3), $100 \mathrm{mM} \mathrm{KCl,} 3 \mathrm{mM} \mathrm{MgCl}_{2}, 500 \mu \mathrm{M}$ $\mathrm{dNTP}$ each, $0.1 \mathrm{U}$ Taq Polymerase/ $\mu \mathrm{l}$. The amplified DNA was digested at $37^{\circ} \mathrm{C}$ for 12 hours with the restriction enzyme MspI (Fermentas, USA), which cuts at the 1438G site. The product was electrophoresed on 3\% agarose gels and stained with ethidium bromide. Homozygous genotypes were identified by the presence of a single 200-bp band $(A A)$, or bands of 121- and 79-bp (GG). The heterozygous genotype $(A G)$ had all three bands.

To genotype the T102C SNP in the $5-\mathrm{HT}_{2 \mathrm{~A}}$ gene, PCR was performed with the forward primer $5^{\prime}$-TCTGCTACAAGTTCTGGCTT-3' and the reverse primer $5^{\prime}$ CTGCAGCTTTTTCTCTAGGG-3' [26]. Amplification was performed using the same methods described for the $5-\mathrm{HT}_{2 \mathrm{~A}} \mathrm{~A}-1438 \mathrm{G}$ SNP. Allele 1 (T102-allele) was represented by the uncut 342 -bp PCR product and allele 2 (C102-allele) consisted of two fragments at 217- and 125-bp.

\section{BDNF genotyping}

The genotyping of Val66Met polymorphism of the BDNF gene was determined by examining the occurrence of a NlaIII recognition site [27]. The PCR assay mixture contained $2 \mu \mathrm{l}$ of $100 \mathrm{ng} / \mu \mathrm{l}$ DNA, $10 \mu \mathrm{l}$ of $2 \times$ Master Mix ( $2 \times$ Taq PCR Master Mix, TIANGEN), $0.5 \mu \mathrm{l}$ of $20 \mu \mathrm{M}$ each primer ( $5^{\prime}$-ACTCTGGAGAGCGTGAAT$3{ }^{\prime}$ and $5^{\prime}$-ATACTGTCACACACGCTC-3') [28], and $7 \mu \mathrm{l}$ of distilled water. The amplification cycle was performed on a $\mathrm{C} 1000^{\mathrm{rm}}$ Thermal Cycler (BIO-RAD, USA). After an initial denaturation at $94^{\circ} \mathrm{C}$ for $5 \mathrm{~min}$, the DNA was amplified by 35 cycles: denaturation at $94^{\circ} \mathrm{C}$ for $30 \mathrm{~s}$, annealing $60^{\circ} \mathrm{C}$ for $30 \mathrm{~s}$ and extension $72^{\circ} \mathrm{C}$ for $1 \mathrm{~min}$, followed by a final extension at $72^{\circ} \mathrm{C}$ for $7 \mathrm{~min}$, the reaction was terminated at $4^{\circ} \mathrm{C}$. PCR products were digested with NlaIII (Fermentas, USA) endonuclease, the product was electrophoresed on 3\% agarose gels and stained with ethidium bromide. The presence of 168 and 75 bp bands indicates the existence of A (Met) allele; the presence of $243 \mathrm{bp}$ band indicates the existence of $\mathrm{G}$ (Val) allele, while the presence of 75, 168 and 243 bp indicates AG (Met/Val) heterozygote.

\section{5-HT $T_{1 A}$ genotyping}

To genotype the C-1019G SNP in the $5-\mathrm{HT}_{1 \mathrm{~A}}$ gene, PCR was performed with the forward primer 5 '-TGGAAGAA GACCGAGTGTGTCTAC-3' and the reverse primer 5' 'TTCTCCCTGAGGGAGTAAGGCTGG-3' [29]. The amplification mixture contained $2 \mu \mathrm{l}$ of $100 \mathrm{ng} / \mu \mathrm{l} \mathrm{DNA}$, $10 \mu \mathrm{l}$ of $2 \times$ Master Mix $(2 \times$ Taq PCR Master Mix, TIANGEN), $0.5 \mu \mathrm{l}$ of $20 \mu \mathrm{M}$ each primer and $7 \mu \mathrm{l}$ of distilled water. Samples were amplified using a $\mathrm{C} 1000^{\mathrm{TM}}$ Thermal Cycler (BIO-RAD, USA) for 36 cycles. After an initial $5 \mathrm{~min}$ at $95^{\circ} \mathrm{C}$, each cycle consisted of $45 \mathrm{~s}$ at $95^{\circ} \mathrm{C}, 45 \mathrm{~s}$ at $56^{\circ} \mathrm{C}$, and $45 \mathrm{~s}$ at $72^{\circ} \mathrm{C}$. After a final $10 \mathrm{~min}$ at $72^{\circ} \mathrm{C}$, the reaction was terminated at $4^{\circ} \mathrm{C}$. The amplified DNA was digested with the restriction enzyme Hpy CH4IV (Fermentas, USA ), which cuts at the $-1019 \mathrm{G}$ site, and the product was electrophoresed in 5\% agarose gels and stained with ethidium bromide. Homozygous genotypes 
were identified by the presence of a single $182 \mathrm{bp}$ band $(\mathrm{C} / \mathrm{C})$, or bands of 158 and $24 \mathrm{bp}(\mathrm{G} / \mathrm{G})$. The heterozygous genotype had three bands: 182, 158, and $24 \mathrm{bp}(\mathrm{C} / \mathrm{G})$.

\section{Statistical analysis}

Data was analyzed using the statistical package for social sciences (SPSS ver.17). Quantitative variables were expressed as mean $\pm \mathrm{SD}$. Differences in variable means between $\mathrm{ABB}$ group and $\mathrm{nABB}$ group were compared by $T$ test. Reported percentages reflect average values. Alleles, genotype frequencies, and individual features between patients and control subjects were compared by Pearson Chi-Square $\left(x^{2}\right)$ and Continuity Correction ChiSquare test. Hardy-Weinberg equilibrium was assessed by Chi-Square analysis. A $P$ value less than 0.05 was considered statistically significant.

\section{Results}

\section{5-HT $2 \mathrm{~A}$ A-1438G polymorphism}

Homozygous genotypes were identified by the presence of a single 200-bp band $(A A)$ or bands of 121- and 79-bp $(G G)$. The heterozygous type $(A G)$ displayed all three band sizes (Figure 1).

The distribution of the A-1438G polymorphism of 5$\mathrm{HT}_{2 \mathrm{~A}}$ in $\mathrm{nABB}$ group and control group were in agreement with the Hardy-Weinberg equilibrium. There were no significant differences between groups $(P>0.05)$. The Hardy-Weinberg equilibria for the candidate gene were as follows: $\mathrm{nABB}$ group, $\mathrm{X}^{2}=0.095, \mathrm{df}=2, P=0.954$; control group, $\chi^{2}=0.665, \mathrm{df}=2, P=0.717$.

Frequencies of $5-\mathrm{HT}_{2 \mathrm{~A}} \mathrm{~A}-1438 \mathrm{G}$ alleles and genotypes in the $\mathrm{ABB}$ group, $\mathrm{nABB}$ group and control group are shown in Table 1 . There were significant differences in the $5-\mathrm{HT}_{2 \mathrm{~A}} \mathrm{~A}-1438 \mathrm{G}$ genotype distributions among the ABB group, $\mathrm{ABBB}$ group and control group $\left(\chi^{2}=13.310\right.$, $P=0.010)$. Compared with the control and $\mathrm{nABB}$ groups, the ABB group had significant differences $\left(X^{2=} 12.760\right.$, $\left.P=0.002 ; \chi^{2}=8.299, P=0.016\right)$ in the A-1438G genotype distributions. Compared to control group, the $\mathrm{nABB}$ group had not a significant difference in the A-1438G genotype distributions $(P>0.05)$. Individuals with the GG (OR 0.176; 95\% CI $0.057 \sim 0.538$ ) genotypes were more likely to not have depression. Moreover, GG genotype seemed to be protective factor. There were no significant differences in the $5-\mathrm{HT}_{2 \mathrm{~A}} \mathrm{~A}-1438 \mathrm{G}$ allele distributions among the $\mathrm{ABB}$ group, $\mathrm{ABB}$ group and control group $\left(X^{2}=1.904, P=0.386\right)$.

\section{5- $\mathrm{HT}_{2 \mathrm{~A}} \mathrm{~T} 102 \mathrm{C}$ polymorphism}

Homozygous genotypes were identified by the presence of a single 342-bp band (TT), or bands of 217- and 125-bp (CC). The heterozygous genotype (TC) had all three bands (Figure 2).

The distribution of the $5-\mathrm{HT}_{2 \mathrm{~A}} \mathrm{~T} 102 \mathrm{C}$ polymorphism in $\mathrm{nABB}$ group and control group were in agreement with the Hardy-Weinberg equilibrium. There were no significant differences between groups $(P>0.05)$. The Hardy-Weinberg equilibria for the candidate gene were as follows: $\mathrm{nABB}$ group $\mathrm{X}^{2}=0.096 \mathrm{df}=2 P=0.953$; control group $\chi^{2}=0.675 \mathrm{df}=2 P=0.714$.

Frequencies of the $5-\mathrm{HT}_{2 \mathrm{~A}} \mathrm{~T} 102 \mathrm{C}$ alleles and genotypes in the $\mathrm{ABB}$ group, $\mathrm{nABB}$ group and control group are shown in Table 1 . There were significant statistical differences in the $5-\mathrm{HT}_{2 \mathrm{~A}} \mathrm{~T} 102 \mathrm{C}$ genotype distributions among the $\mathrm{ABB}$ group, $\mathrm{nABB}$ group, and control group $\left(X^{2}=15.686, P=0.003\right)$. Compared with the control and nABB groups, the ABB group had significant differences $\left(X^{2}=15.602, P=0.000 ; X^{2}=9.074, P=0.011\right)$ in the T102C genotype distributions. Compared to control group, the nABB group had not a significant difference $(P>0.05)$ in the $\mathrm{T} 102 \mathrm{C}$ genotype distributions. Individuals with the CC (OR 0.139; 95\% CI $0.042 \sim 0.463$ ) genotypes were

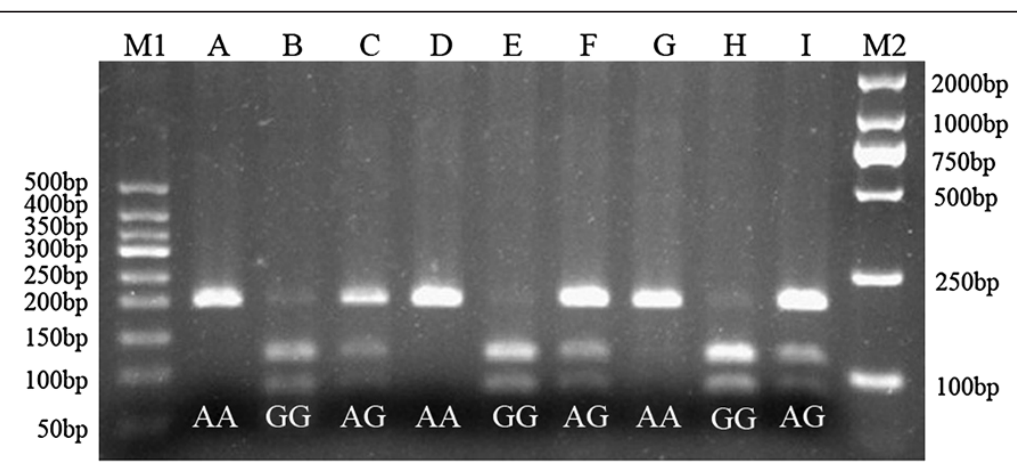

Figure 1 Agarose gel eletrophoretogram of $5-\mathrm{HT}_{2 \mathrm{~A}} \mathrm{~A}-1438 \mathrm{G}$ PCR product after digestion with Mspl. The distribution of the A-1438G polymorphism of 5-HT2A in $\mathrm{ABBB}$ group and control group were in agreement with the Hardy-Weinberg equilibrium. There were no significant differences between groups (P>0.05). Lane M1: 50 bp DNA Ladder; Lane A, D, and G: AA; Lane B, E, and H: GG; Lane C, F, and I: AG; Lane M2: 2000 bp DNA marker. 
Table 1 5-HT2A A-1438G, 5-HT2A T102C, BDNF Val66Met, and 5-HT1A C-1019G genotype and allele distribution in depression patients and controls

\begin{tabular}{|c|c|c|c|c|c|}
\hline $\begin{array}{l}\text { Genotype } \\
\text { and allele }\end{array}$ & $\begin{array}{c}\text { ABB group }(n=106) \\
n(\%)\end{array}$ & $\begin{array}{c}\text { nABB group }(n=89) \\
n(\%)\end{array}$ & $\begin{array}{c}\text { Control group }(n=50) \\
n(\%)\end{array}$ & $x^{2}$ & $P$ value \\
\hline \multicolumn{6}{|l|}{ 5-HT2A A-1438G } \\
\hline Genotype AA & $34(32.1)$ & $29(32.6)$ & $18(36.0)$ & 13.31 & 0.01 \\
\hline$A G$ & $67(63.2)$ & 45(50.6) & $21(42.0)$ & & \\
\hline$G G$ & $5(4.7)$ & $15(16.9)$ & $11(22.0)$ & & \\
\hline$P$ value & $0.002^{\mathrm{a}}$ & 0.59 & & & \\
\hline Alleles A & 135(63.7) & 103(57.9) & $57(57.0)$ & 1.9 & 0.39 \\
\hline G & $77(36.3)$ & $75(42.1)$ & $43(43.0)$ & & \\
\hline$P$ value & 0.26 & 0.89 & & & \\
\hline \multicolumn{6}{|l|}{ 5-HT2A T102C } \\
\hline Genotype TT & $34(32.1)$ & $30(33.7)$ & 19(38.0) & 15.69 & 0 \\
\hline TC & $68(64.2)$ & $45(50.6)$ & $20(40.0)$ & & \\
\hline$C C$ & $4(3.8)$ & $14(15.7)$ & $11(22.0)$ & & \\
\hline$P$ value & $0.000^{b}$ & 0.44 & & & \\
\hline Alleles T & 136(64.2) & 105(59.0) & $58(58.0)$ & 1.57 & 0.46 \\
\hline C & $76(35.8)$ & $73(41.0)$ & $42(42.0)$ & & \\
\hline$P$ value & 0.3 & 0.87 & & & \\
\hline \multicolumn{6}{|l|}{ BDNF Val66Met } \\
\hline Genotype Val/Nal & $51(48.1)$ & $35(39.3)$ & $12(24.0)$ & 17.79 & 0 \\
\hline MetNal & $51(48.1)$ & $42(47.2)$ & $26(52.0)$ & & \\
\hline Met/Met & $4(3.8)$ & $12(13.5)$ & $12(24.0)$ & & \\
\hline$P$ value & $0.040^{c}$ & 0.11 & & & \\
\hline Alleles Val & $153(72.2)$ & $112(63.0)$ & $50(50.0)$ & 14.77 & 0 \\
\hline Met & $59(27.8)$ & $66(37.0)$ & $50(50.0)$ & & \\
\hline$P$ value & $0.000^{d}$ & 0.04 & & & \\
\hline \multicolumn{6}{|l|}{ 5-HT1A C-1019G } \\
\hline Genotype CC & $46(43.4)$ & $40(45.0)$ & $15(30.0)$ & 14.63 & 0.01 \\
\hline CG & $55(51.9)$ & $35(39.3)$ & $23(46.0)$ & & \\
\hline GG & $5(4.7)$ & $14(15.7)$ & $12(24.0)$ & & \\
\hline$P$ value & $0.001^{e}$ & 0.19 & & & \\
\hline Alleles C & $147(69.3)$ & 115(64.6) & $53(53.0)$ & 7.91 & 0.02 \\
\hline G & $65(30.7)$ & $63(35.4)$ & $47(47.0)$ & & \\
\hline$P$ value & $0.005^{f}$ & 0.06 & & & \\
\hline
\end{tabular}

${ }^{a}$ Odds ratio (and 95\% confidence interval) for $G G$ vs $(A / G+A / A)$ is 0.176(0.057 0.538), $x 2=11.025, d f=1, P=0.001$

bodds ratio (and 95\% confidence interval) for CC vs $(T / C+T / T)$ is $0.139(0.042 \sim 0.463), X 2=12.987, d f=1, P=0.000$.

COdds ratio (and 95\% confidence interval) for Val/Val vs (Val/Met + Met/Met) is 2.936(1.383 6.232), $\mathrm{X} 2=8.205, \mathrm{df}=1, \mathrm{P}=0.004$, and $\mathrm{Met} / \mathrm{Met} \mathrm{vs} \mathrm{Val} / \mathrm{Met}+\mathrm{Val} / \mathrm{Val}$ is $0.124(0.038 \sim 0.409), \mathrm{X} 2=15.100, \mathrm{df}=1, \mathrm{P}=0.000$.

${ }^{\mathrm{d} O d d s}$ ratio (and 95\% confidence interval) for Met allele vs Val allele is $2.936(1.383 \sim 6.232$ ), $\mathrm{X} 2=14.692, \mathrm{df}=1, \mathrm{P}=0.000$.

${ }^{e}$ Odds ratio (and 95\% confidence interval) for GG vs $(G / C+C / C)$ is $0.157(0.052 \sim 0.475), x 2=13.010, d f=1, P=0.000$.

${ }^{f}$ Odds ratio (and 95\% confidence interval) for $C$ allele vs $G$ allele is $2.006(1.229 \sim 3.271$ ), $X 2=7.884, d f=1, P=0.005$.

more likely to not have depression. Moreover, $C C$ genotype seemed to be protective factor. There were no significant differences in the $5-\mathrm{HT}_{2 \mathrm{~A}} \mathrm{~T} 102 \mathrm{C}$ allele distributions among the $\mathrm{ABB}, \mathrm{nABB}$ and control group $\left(\mathrm{X}^{2}=1.566, P=0.457\right)$.

\section{BDNF Val66Met polymorphism}

Homozygous genotypes were identified by the presence of a single 243-bp band ( $\mathrm{Val} / \mathrm{Val})$, or bands of 75 - and 168-bp (Met/Met). The heterozygous genotype (Met/Val) had all three bands (Figure 3). 


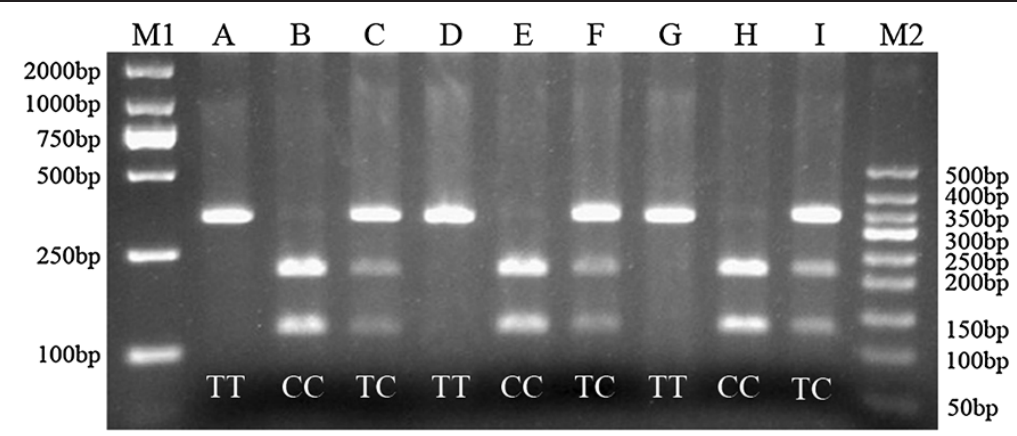

Figure 2 Agarose gel eletrophoretogram of 5- $\mathrm{HT}_{2 \mathrm{~A}} \mathrm{~T} 102 \mathrm{C}$ PCR product after digestion with Mspl. The distribution of the 5- $\mathrm{HT} 2 \mathrm{~A} 102 \mathrm{C}$ polymorphism in $\mathrm{nABB}$ group and control group were in agreement with the Hardy-Weinberg equilibrium. There were no significant differences between groups $(P>0.05)$. Lane M1: 2000 bp DNA marker; Lane A, D, and G: TT; Lane B, E, and H: CC; Lane C, F, and I: TC; Lane M2: 50 bp DNA Ladder.

The distribution of the BDNF Val66Met polymorphism in the $\mathrm{ABB}$ group, $\mathrm{nABB}$ group and control group were in agreement with the Hardy-Weinberg equilibrium. There were no significant differences between groups $(P>0.05)$. The Hardy-Weinberg equilibria for the candidate gene were as follows: $\mathrm{ABB}$ group, $\mathrm{X}^{2}=2.165, \mathrm{df}=2, P=0.339$; nABB group, $X^{2}=0.006, \mathrm{df}=2, P=0.997$; control group, $X^{2}=0.090, \mathrm{df}=2, P=0.956$.

The genotype and allele frequency distributions of BDNF Val66Met polymorphism in patients and control subjects is shown in Table 1 . There were significant statistical differences in the BDNF Val66Met genotype distributions among the $\mathrm{ABB}$ group, $\mathrm{nABB}$ group, and control group ( $\left.X^{2}=17.793, P=0.001\right)$. Compared with the control and $\mathrm{nABB}$ groups, the $\mathrm{ABB}$ group had significant differences $\left(\chi^{2}=6.414, P=0.040 ; \chi^{2}=18.547, P=0.000\right)$ in the BDNF Val66Met genotype distributions. Compared to control group, the nABB group had not a significant difference $(P>0.05)$ in the Val66Met genotype distributions. Individuals with the Met/Met (OR 0.124; 95\% CI $0.038 \sim 0.409)$ genotypes were more likely to not have depression. Moreover, Met/Met genotype seemed to be protective factor. In case of the genotypic association of BDNF, analyses using the recessive model showed association between the SNP and the risk of depression $\left(x^{2}=8.205, P=0.004\right)$. Individuals with the Met allele more likely to be have depression (OR 2.936; 95\% CI $1.383 \sim 6.232$ for the recessive model). There were significant differences in the BDNF Val66Met allele distributions among the $\mathrm{ABB}, \mathrm{nABB}$ and control group $\left(X^{2}=14.773, P=0.001\right)$.

\section{5-HT 1 A $\mathrm{C}-1019 \mathrm{G}$ polymorphism}

Homozygous genotypes were identified by the presence of a single 182-bp band $(C / C)$, or bands of 24- and 158-bp $(G / G)$. The heterozygous genotype $(C / G)$ had all three bands (Figure 4).

The distribution of the $5-\mathrm{HT}_{1 \mathrm{~A}} \mathrm{C}-1019 \mathrm{G}$ polymorphism in the $\mathrm{ABB}$ group, $\mathrm{nABB}$ group and control group were in agreement with the Hardy-Weinberg equilibrium. There were no significant differences between groups $(P>0.05)$. The Hardy-Weinberg equilibria for the candidate gene were as follows: $A B B$ group, $X^{2}=2.924, \mathrm{df}=2, P=0.232$; nABB group, $X^{2}=0.951, \mathrm{df}=2, P=0.622$; control group, $\chi^{2}=0.161, \mathrm{df}=2, P=0.923$.

The genotype and allele frequency distribution of $5-\mathrm{HT}_{1 \mathrm{~A}} \mathrm{C}-1019 \mathrm{G}$ polymorphism in patients and control subjects is shown in Table 1. There were significant

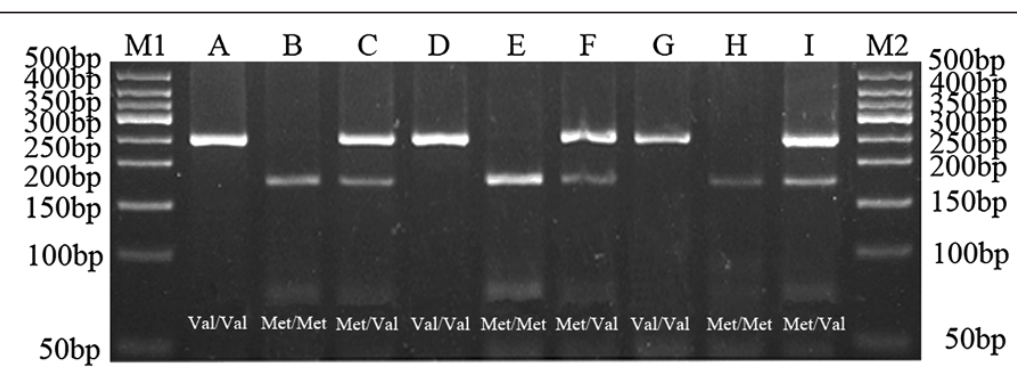

Figure 3 Agarose gel eletrophoretogram of BDNF Val66Met PCR product after digestion with Nlall. The distribution of the BDNF Val66Met polymorphism in the ABB group, nABB group and control group were in agreement with the Hardy-Weinberg equilibrium. There were no significant differences between groups ( $P>0.05)$. Lane M1: 50 bp DNA Ladder; Lane A, D, and G: ValNal; Lane B, E, and H: Met/Met; Lane C, F, and I: MetNal; Lane M2: 50 bp DNA Ladder. 


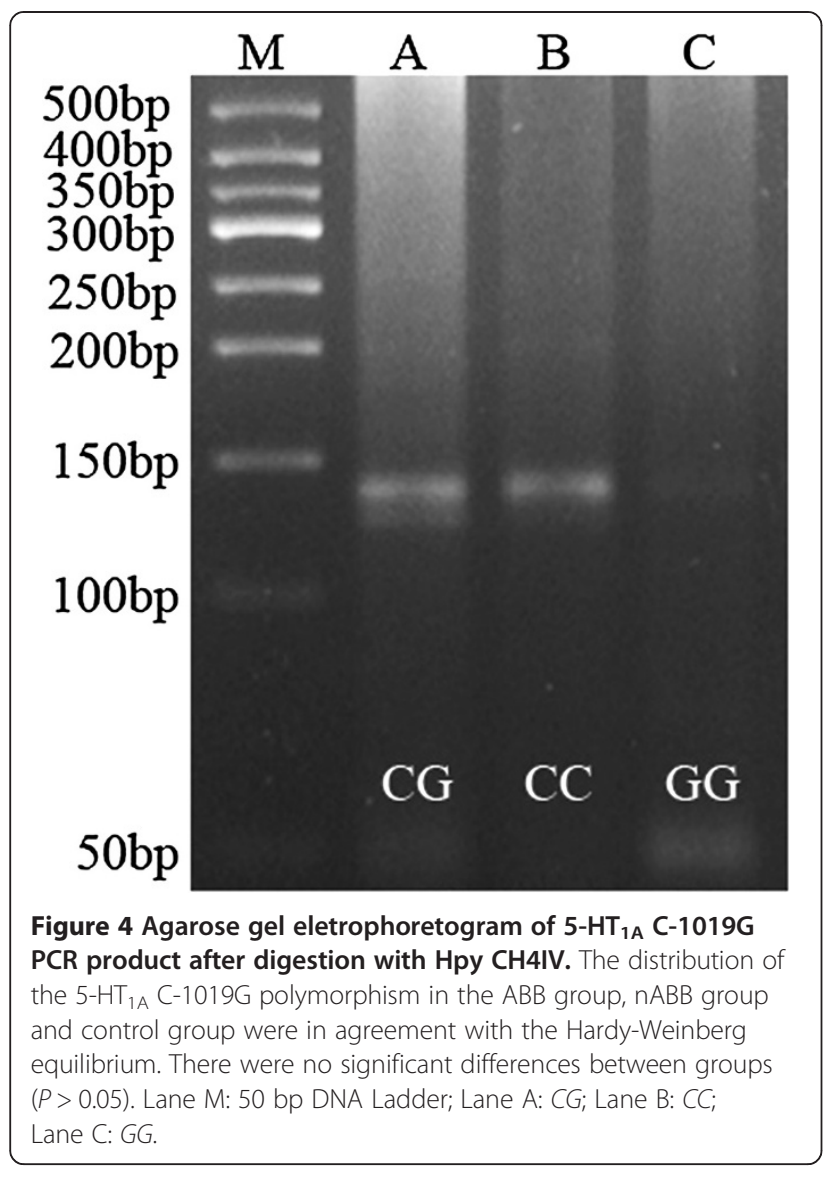

statistical differences in the $5-\mathrm{HT}_{1 \mathrm{~A}} \mathrm{C}-1019 \mathrm{G}$ genotype distributions among the $\mathrm{ABB}$ group, $\mathrm{nABB}$ group, and control group $\left(X^{2}=14.633, P=0.006\right)$. Compared with the control and $\mathrm{nABB}$ groups, the $\mathrm{ABB}$ group had significant differences $\left(X^{2}=7.703, P=0.021 ; X^{2}=13.387, P=0.001\right)$ in the $5-\mathrm{HT}_{1 \mathrm{~A}} \mathrm{C}-1019 \mathrm{G}$ genotype distributions. Compared to the control group, the nABB group had not significant differences $(\mathrm{P}>0.05)$ in the $5-\mathrm{HT}_{1 \mathrm{~A}} \mathrm{C}-1019 \mathrm{G}$ genotype distributions. Individuals with the GG (OR 0.157; $95 \%$ CI $0.052 \sim 0.475)$ genotypes were more likely to not have depression. Moreover, GG genotype seemed to be protective factor. There were significant differences in the $5-\mathrm{HT}_{1 \mathrm{~A}} \mathrm{C}-1019 \mathrm{G}$ allele distributions among the $\mathrm{ABB}, \mathrm{nABB}$ and control group $\left(\chi^{2}=7.914, P=0.019\right)$.

\section{Interaction analysis between the $5-\mathrm{HT}_{2 \mathrm{~A}} \mathrm{~T} 102 \mathrm{C}$ and} $5-\mathrm{HT}_{2 \mathrm{~A}} \mathrm{~A}-1438 \mathrm{G}$ polymorphisms in $\mathrm{ABB}$ patients and healthy volunteers

The two polymorphisms were in linkage disequilibrium. Table 2 shows that $93.3 \%$ of $\mathrm{ABB}$ and $78.0 \%$ of controls homozygous for $102 \mathrm{~T}$ were also homozygous for $-1438 \mathrm{~A}$. In addition, $65.1 \%$ of ABB and $62.0 \%$ of controls homozygous for $102 \mathrm{C}$ were also homozygous for $-1438 \mathrm{G}$ allele. The $-1438 \mathrm{~A}$ and $102 \mathrm{~T}$ allele frequencies were higher among $\mathrm{ABB}$ (0.64 and 0.64, respectively) than in controls
Table 2 Genotype distribution (n (\%)) of T102C and A-1438G polymorphisms of the 5-HT2A gene among ABB patients and healthy volunteers

\begin{tabular}{rccc}
\hline & $\mathbf{1 0 2} \mathbf{T T}$ & $\mathbf{1 0 2 ~ T C}$ & $\mathbf{1 0 2 ~ C C}$ \\
\hline ABB group $(\mathrm{n}=106)$ & & & \\
$-1438 \mathrm{AA}$ & $31(29.2)$ & $3(2.8)$ & \\
$-1438 \mathrm{AG}$ & $3(2.8)$ & $62(58.5)$ & $2(1.9)$ \\
$-1438 \mathrm{GG}$ & & $3(2.8)$ & $2(1.9)$
\end{tabular}

Control group $(n=50)$

\begin{tabular}{lccc}
$-1438 \mathrm{AA}$ & $18(36.0)$ & & \\
$-1438 \mathrm{AG}$ & $1(2.0)$ & $20(40.0)$ & \\
$-1438 \mathrm{GG}$ & & & $11(22.0)$ \\
\hline
\end{tabular}

( 0.57 and 0.58 , respectively). The OR associated with the presence of $-1438 \mathrm{~A}$ plus $102 \mathrm{~T}$ alleles was 3.989 for $\mathrm{ABB}$ compared with controls (OR 3.989; 95\% CI 1.442 11.035; $P=0.005)$ (Table 2).

Interaction analysis between the BDNF Val66Met and $5-\mathrm{HT}_{1 \mathrm{~A}} \mathrm{C}-1019 \mathrm{G}$ polymorphisms in $\mathrm{ABB}$ patients and healthy volunteers

Significant difference was observed between the $A B B$ and control groups $\left(X^{2}=14.692, P=0.000\right)$ in the BDNF Val66Met allele distribution. The $\mathrm{Val}$ allele was associated with 2.593 fold increased risk for depression compared with Met allele (OR 2.593; 95\% CI 1.583 4.249). Moreover, there was a significant difference in the $5-\mathrm{HT}_{1 \mathrm{~A}}$ C-1019G allele distribution between the ABB and control groups $\left(\chi^{2}=7.884, P=0.005\right)$. The $C$ allele was associated with 2.006 fold increased risk for depression compared with $G$ allele (OR 2.006; 95\% CI 1.229 3.271).

The OR associated with the combination of Val66Met$\mathrm{Val} / \mathrm{Val}$ genotype plus the presence of $-1019 \mathrm{C}$ allele was 8.393 for ABB compared with controls (OR 8.393; 95\% CI $1.807 \sim 38.991 ; P=0.003)$. Moreover, the OR associated with the presence of - Met plus $-1019 \mathrm{C}$ alleles was 12.194 for $\mathrm{ABB}$ compared with controls (OR 12.194; 95\% CI 1.433 103.776; $P=0.005)$. The OR associated with the presence of $-1438 \mathrm{C} / \mathrm{C}$ plus $\mathrm{Val} / \mathrm{Val}$ genotypes was 7.738 for $\mathrm{ABB}$ compared with controls (OR 7.738; 95\% CI $1.566 \sim 38.241 ; P=0.005$ ) (Table 3).

\section{Identification of independent risk factors for $\mathrm{ABB}$}

Table 4 presents the estimated logistic regression coefficients, estimated SEs, adjusted odds ratios (ORs), and 95\% confidence intervals (CIs) for the adjusted ORs for the final model for admissions. After adjusting for those conventional depression risk factors such as age, gender, the $A A$ (of the A-1438G polymorphisms of the $5-\mathrm{HT}_{2 \mathrm{~A}}$ gene), $\mathrm{Val} / \mathrm{Val}$ (of the Val66Met polymorphisms of the BDNF gene), CC (of the C-1019G polymorphisms of the $5-\mathrm{HT}_{1 \mathrm{~A}}$ gene) genotype still had an approximately. A 
Table 3 BDNF Val66Met (5-HT1A C-1019G) genotype frequency in ABB patients and healthy volunteers according to 5-HT1A C-1019G (BDNF Val66Met) genotype

\begin{tabular}{|c|c|c|c|c|c|}
\hline \multicolumn{2}{|c|}{ Genotypes } & \multicolumn{2}{|c|}{ Genotype frequency (n (\%)) } & \multirow[t]{2}{*}{$P$ value } & \multirow[t]{2}{*}{ OR(95\% Cl) } \\
\hline & & ABB group $(n=106)$ & Control group $(n=50)$ & & \\
\hline \multirow[t]{4}{*}{ Val66Met } & C-1019G & & & & \\
\hline & CC & $25(49.0)$ & $2(16.7)$ & 0 & 1 \\
\hline & CG & $22(43.2)$ & $5(41.7)$ & & \\
\hline & GG & $4(7.8)$ & $5(41.7)$ & & $8.393(1.807 \sim 38.991)$ \\
\hline \multirow[t]{3}{*}{ Met/Nal + Met/Met } & CC & $21(38.2)$ & 13(34.2) & 0.01 & 1 \\
\hline & CG & $33(60.0)$ & 18(47.4) & & \\
\hline & GG & $1(1.8)$ & $7(18.4)$ & & 12.194(1.433 103.776) \\
\hline \multirow[t]{5}{*}{ C-1019G } & Val66Met & & & & \\
\hline & ValNal & $25(54.3)$ & $2(13.3)$ & 0.01 & 1 \\
\hline & Met/Nal + Met/Met & $21(45.7)$ & 13(86.7) & & $7.738(1.566 \sim 38.241)$ \\
\hline & ValNal & $22(40.0)$ & $5(21.7)$ & 0.12 & 1 \\
\hline & Met/Nal + Met/Met & $33(60.0)$ & 18(78.3) & & $2.400(0.777 \sim 7.416)$ \\
\hline \multirow[t]{2}{*}{ GG } & ValNal & $4(80.0)$ & $5(41.7)$ & 0.15 & 1 \\
\hline & Met/Nal + Met/Met & $1(20.0)$ & $7(58.3)$ & & $5.600(0.472 \sim 66.447)$ \\
\hline
\end{tabular}

multiple logistic regression model showed 5 independent factors: Gender (OR=0.365, 95\% CI: 0.136-0.982; $P<0.05)$, Age $(\mathrm{OR}=4.806,95 \% \mathrm{CI}: 2.476-9.328 ; P<0.01), \quad A A$ (OR=13.759, 95\% CI: 2.225-85.076; $P<005$; for $5-\mathrm{HT}_{2 \mathrm{~A}}$ A-1438G), $\mathrm{Val} / \mathrm{Val}(\mathrm{OR}=39.791,95 \% \mathrm{CI}: 5.365-295.110$; $P<0.01), C C(\mathrm{OR}=7.309$, 95\% CI: 1.349-39.597; $P<0.05$; for $\left.5-\mathrm{HT}_{1 \mathrm{~A}} \mathrm{C}-1019 \mathrm{G}\right)$. In addition, we found $\mathrm{Val} / \mathrm{Met}$ genotype of the BDNF Val66Met gene is also an independent risk factor for $\mathrm{ABB}$ with an odds ratio of 6.854-fold higher relative risk of developing $\mathrm{ABB}$ than those with the Met/Met homozygote $(\mathrm{OR}=6.854,95 \% \mathrm{CI}: 1.092-43.033$; $P<0.05)$, also $A G(\mathrm{OR}=32.889$, 95\% CI: 4.981-217.178; $P<0.01$; for $\left.5-\mathrm{HT}_{2 \mathrm{~A}} \mathrm{~A}-1438 \mathrm{G}\right)$ and $C G(\mathrm{OR}=7.420,95 \%$

Table 4 Results of logistic analysis

\begin{tabular}{lcccccc}
\hline & \multicolumn{5}{c}{ ABB } \\
\cline { 2 - 7 } & B & S.E. & Wald & $\boldsymbol{P}$ & OR & 95\% C.I. \\
\hline Gender & -1.01 & 0.51 & 3.98 & 0.05 & 0.37 & $0.136-0.982$ \\
Age & 1.57 & 0.34 & 21.52 & 0 & 4.81 & $2.476-9.328$ \\
A1438G(GG) & & & 13.36 & 0 & & \\
A1438G(AA) & 2.62 & 0.93 & 7.95 & 0.01 & 13.76 & $2.225-85.076$ \\
A1438G(AG) & 3.49 & 0.96 & 13.16 & 0 & 32.89 & $4.981-217.178$ \\
BDNF(Met/Met) & & & 15.37 & 0 & & \\
BDNF(Val/Nal) & 3.68 & 1.02 & 12.98 & 0 & 39.79 & $5.365-295.110$ \\
BDNF(Val/Met) & 1.93 & 0.94 & 4.22 & 0.04 & 6.85 & $1.092-43.033$ \\
5-HT1A(GG) & & & 5.74 & 0.06 & & \\
5-HT1A(CC) & 1.99 & 0.86 & 5.32 & 0.02 & 7.31 & $1.349-39.597$ \\
5-HT1A(CG) & 2 & 0.9 & 5 & 0.03 & 7.42 & $1.282-42.965$ \\
Constant & -7.28 & 1.66 & 19.21 & 0 & 0 & \\
\hline
\end{tabular}

CI: $1.282-42.965 ; P<0.05$; for $5-\mathrm{HT}_{1 \mathrm{~A}} \mathrm{C}-1019 \mathrm{G}$ ) genotypes are an independent risk factor for ABB.

\section{Discussion}

Traditional Uighur Medicine (TUM), a well-known medical system in China for their remarkable curative effect, is based on the concept of equilibrium and balance of natural body humors (blood, phlegm, yellow bile, and black bile). The imbalance in the quality and quantity of these humors leads to diseases whereas restoration of this balance maintains health of a person [10]. Abnormal humors include abnormal blood, abnormal phlegm, abnormal yellow bile and abnormal black bile. According to TUM, abnormal black bile is a special humor in the body, and is the main cause of complex diseases such as tumors, diabetes mellitus, hypertension, and depression [12].

In this study, we evaluated the individual and interaction effects of depression related gene polymorphisms in depression with abnormal humor. Our results indicated that there were significant interactions of the T102C and A1438G SNPs in 5- $\mathrm{HT}_{2 \mathrm{~A}}$ receptor gene, Val66Met SNP in BDNF gene, and C-1019G SNP in $5-\mathrm{HT}_{1 \mathrm{~A}}$ receptor gene with depression with abnormal humor. Moreover, the present study showed a significant interaction between the BDNF Val66Met and 5-HT ${ }_{1 \mathrm{~A}} \mathrm{C}-1019 \mathrm{G}$ polymorphisms.

The present study on $\mathrm{ABB}$ revealed significant difference in the prevalence of $5-\mathrm{HT}_{2 \mathrm{~A}} \mathrm{~T} 102 \mathrm{C}$ and $5-\mathrm{HT}_{2 \mathrm{~A}}$ A-1438G genotype frequency compared with that of controls and $\mathrm{nABB}$ patients. These results reported here in a Chinese population were not in agreement with those reported by Dawei $\mathrm{Li}$, who found no association of the $\mathrm{T} 102 \mathrm{C}$ polymorphism with either schizophrenia or 
suicidal behavior, evidence of significant association was only detected between the A-1438G polymorphism and suicidal behavior [30]. Our results failed to confirm previous reports that genotype frequencies of $102 \mathrm{~T} / \mathrm{C}$ $5-\mathrm{HT}_{2 \mathrm{~A}}$ receptor gene polymorphism in mood disorders do not differ from healthy volunteers [31-33]. Moreover, Ho-kyoung Yoon concluded that the $5-\mathrm{HT}_{2 \mathrm{~A}} \mathrm{~T} 102 \mathrm{C}$ polymorphism may not be associated with susceptibility to suicidal behavior in Korean population [34]. We postulate that the differences in the genotype frequencies between our study and previous reports may be the result of ethnic differences of patients participated in these studies. Furthermore, no difference was found in $5-\mathrm{HT}_{2 \mathrm{~A}} \mathrm{~T} 102 \mathrm{C}$ genotype and allele distribution between the mood disordered subjects, with and without suicide attempt history, and controls [35]. The authors concluded that their study did not support the association of the $5-\mathrm{HT}_{2 \mathrm{~A}}$ gene with either schizophrenia or suicidal behavior. The results showed a higher frequency of 5$\mathrm{HT}_{2 \mathrm{~A}}-1438 \mathrm{~A}$ and $102 \mathrm{~T}$ alleles in $\mathrm{ABB}$ compared to controls. We found that the 1438G, $102 \mathrm{~T}$ alleles and the homozygosity for these alleles were significantly more frequent among the patients with $\mathrm{ABB}$ than among the controls, suggesting that the allele is associated with susceptibility to depression. We also found that $A A$ (or $T T$ ) genotype is an independent risk factor for $\mathrm{ABB}$ according to the multiple logistic regression models.

In this study, we found a significant difference among the $\mathrm{Val} / \mathrm{Val}$, Val/Met, and Met/Met genotypes or between $\mathrm{Val}$ and $\mathrm{Met}$ alleles in ABB group patients compared with the controls and $\mathrm{nABB}$ patients. Our results reported here in a Chinese population are in agreement with those reports such as BDNF may have a major role in the pathogenesis and treatment response of depression [36]. Two meta-analyses have suggested that BDNF is associated with depression or the response to antidepressants [37,38], while another meta-analysis showed no association [39]. In this study, ABB individuals with the major allele ( $\mathrm{Val} / \mathrm{Val})$ had an odds ratio of 2.9, also $\mathrm{Val} / \mathrm{Val}$ genotype is an independent risk factor for $\mathrm{ABB}$ according to the multiple logistic regression models. Our results confirmed previous reports that BDNF polymorphism is associated with increased risk of depression in some studies $[40,41]$, as some studies found no association [18,42-44]. In our study $\mathrm{Val}$ allele has a higher distribution in the Chinese population, and $\mathrm{Val} / \mathrm{Val}$ genotype or carrying Val allele of BDNF Val66Met polymorphism is associated with higher response to depression. Approximately $30 \%-50 \%$ of people worldwide are either heterozygous ( $\mathrm{Val} / \mathrm{Met}$ ) or homozygous (Met/Met) for the methionine substitution [45]. Although there is a wealth of information about individuals heterozygous for the Met polymorphism, little information exists about individuals who are homozygous for the Met allele (Met/Met), because this genotype is rare in the general population, comprising only $4 \%$ of people in the United States [45]. In studies of brain morphometry using structural MRI scans, Val/Met individuals have repeatedly been shown to have a smaller hippocampal volume relative to controls to who are homozygous for the $\mathrm{Val}$ allele $(\mathrm{Val} / \mathrm{Val})[46,47]$. This difference may be related to the role BDNF and its receptors play in the development as well as continued plasticity of the brain [48,49].

In this study, we found a significant difference between 5- $\mathrm{HT}_{1 \mathrm{~A}}$ gene $C C, C G$, and $G G$ genotype or between $C$ and $G$ allele in $A B B$ group patients compared with the controls and $\mathrm{nABB}$ patients. We found that the $C C$ allele and the homozygosity for this allele were significantly more frequent among the patients with $\mathrm{ABB}$ than among the controls, suggesting that the allele is associated with susceptibility to depression. Our results were not in agreement with these reports that GG genotype is associated with increased risk of depression [22] and suicide [21]. In our study $C$ allele has a higher distribution in the Chinese population, and $C C$ genotype or carrying $C$ allele of 5$\mathrm{HT}_{1 \mathrm{~A}} \mathrm{C} 1019 \mathrm{G}$ gene is associated with higher response to depression patients with abnormal humor syndrome. We also found that $\mathrm{ABB}$ individuals with the major allele $(C C)$ had an odd ratio of 1.8; $C C$ genotype is an independent risk factor for $\mathrm{ABB}$ according to the multiple logistic regression models.

In the present study, subjects carrying both $5-\mathrm{HT}_{1 \mathrm{~A}}$ C1019G polymorphism CC genotype and $\mathrm{Val} / \mathrm{Val}$ genotype of BDNF Val66Met polymorphism had over seven times higher risk of depression than those who did not have this combination of polymorphisms. We reported a significant association between combined polymorphisms of $5-\mathrm{HT}_{1 \mathrm{~A}}$ and $\mathrm{BDNF}$ polymorphisms and our result was in line with earlier reports [50].

In summary, the present study demonstrated that the A-1438 and $\mathrm{T} 102 \mathrm{C}$ polymorphisms of the $5-\mathrm{HT}_{2 \mathrm{~A}}$ receptor gene, BDNF Val66Met, and 5- $\mathrm{HT}_{1 \mathrm{~A}} \mathrm{C}-1019 \mathrm{G}$ might predict the incidence of depression induced by abnormal black bile. The results showed a higher frequency of 5$\mathrm{HT}_{2 \mathrm{~A}}-1438 \mathrm{~A}$ and $102 \mathrm{~T}$ alleles. $5-\mathrm{HT}_{2 \mathrm{~A}}-1438 \mathrm{~A}$ and $102 \mathrm{~T}$ polymorphisms were in linkage disequilibrium. $\mathrm{ABB}$ individuals with the major allele $(\mathrm{Val} / \mathrm{Val})$ had a three times of odds ratio, also ABB individuals with the major allele $(C C)$ had a two times of odds ratio. The $A A$, $\mathrm{Val} / \mathrm{Val}$, and $\mathrm{CC}$ genotypes were independent risk factors for the ABB. There was a significant association between combined polymorphisms of $5-\mathrm{HT}_{1 \mathrm{~A}}$ and BDNF polymorphisms. However, it was the first study to investigate the association of multiple gene polymorphisms and depression with abnormal humor in TUM. Of course, as an ancient medical system, principles of TUM classification of depression contain a variety of 
biological foundation. But the present study at least to provide new ideas for individualized diagnosis, prevention, treatment of depression.

\section{Conclusions}

It was concluded that there were significant relationship between the gene polymorphisms and classification of depression with abnormal humor in TUM. The 5-HT2A A-1438G, 5-HT2A T102C, BDNF Val66Met, and 5-HT1A C-1019G gene polymorphisms might predict the incidence of depression with $\mathrm{ABB}$. It was the first study to investigate the association of multiple gene polymorphisms and depression with abnormal humor in TUM. Of course, as an ancient medical system, principles of TUM classification of depression contain a variety of biological foundation. But the present study at least to provide new ideas for individualized diagnosis, prevention, treatment of depression.

\begin{abstract}
Abbreviations
TUM: Traditional Uighur medicine; ABB: Abnormal black bile; nABB: None abnormal black bile; PCR-RFLP: Polymerase chain reaction-restriction fragment length polymorphism; SNPS: Single nucleotide polymorphisms; 5- $\mathrm{HT}_{2 \mathrm{~A}}$ : Serotonin 2A; 5- $\mathrm{HT}_{1 \mathrm{~A}}$ : Serotonin 1A; BDNF: Brain derived neurotrophic factor; CCMD-3: Mood disorder standard of Chinese classification of mental disorders; HAMD: Hamilton rating scale for depression.
\end{abstract}

\section{Competing interests}

The authors declare that they have no competing interests.

\section{Authors' contributions}

AY designed the study. HU performed genotyping, made statistical analysis, managed literature search, interpreted the data and wrote the manuscript. AA collected samples. HU (corresponding author) gave comments to the manuscript. All authors read and approved the final manuscript.

\section{Acknowledgments}

The present study was supported by the National Natural Science Foundation of China (No: 81360667) and by a research grant for Yangtze River scholar, Ministry of Education of the People's Republic of China (No: IRT0977).

Received: 3 June 2013 Accepted: 21 November 2013 Published: 25 November 2013

\section{Reference}

1. Chisholm D, Sanderson K, Ayuso-Mateos JL, Saxena S: Reducing the global burden of depression: population-level analysis of intervention costeffectiveness in 14 world regions. Br J Psychiatry 2004, 184:393-403.

2. Insel TR, Charney DS: Research on major depression: strategies and priorities. JAMA 2003, 289(23):3167-3168.

3. Krishnan $\mathrm{V}$, Nestler EJ: The molecular neurobiology of depression. Nature 2008, 455(7215):894-902.

4. Evans DL, Charney DS, Lewis L, Golden RN, Gorman JM, Krishnan KR, Nemeroff CB, Bremner JD, Carney RM, Coyne JC, et al: Mood disorders in the medically ill: scientific review and recommendations. Biol Psychiatry 2005, 58(3):175-189.

5. Krishnan V, Nestler EJ: Linking molecules to mood: new insight into the biology of depression. Am J Psychiatry 2010, 167(11):1305-1320.

6. Arikha N: Passions and Tempers: A History of Humor. New York: Harper Collins Publishers; 2007:10.

7. Wong ML, Licinio J: Research and treatment approaches to depression. Nat Rev Neurosci 2001, 2(5):343-351.

8. Miller G: Psychiatry. Beyond DSM: seeking a brain-based classification of mental illness. Science 2010, 327(5972):1437.
9. Avicenna (adapted by Laleh Bakhtiar): Canon of Medicine (al-Qanun fi al-tibb), Volume I. Chicago: Great Books of the Islamic World, Kazi Publications; 1999

10. Upur H, Yusup A, Umar A, Moore N: Uighur traditional medicine syndrome of Abnormal Savda in men is associated with oxidative stress, which can be improved by Munziq and Mushil of Abnormal Savda. Therapie 2004, 59(4):483-484.

11. Upur H, Yusup A: New Conception on the Theory of Abnormal Black Bile in Traditional Uighur Medicine. Urumqi, China: Xinjiang Science and Technology Press; 2009.

12. Upur H, Yusup A: Theory of Mizaj and Hilit in Uighur Medicine and Modern Study. Urumqi, China: Xinjiang Science and Technology Press; 2003.

13. Dai W, Renagul A, Upur H, Peng X: Study of serotonin transporter gene polymorphisms in disease of patients with abnormal black Savda. Wei Sheng Yan Jiu 2009, 38:265-269.

14. Renaguli A, Meryemgul M, Yusup A: Study on the correlation between pre-thrombotic biomarkers and traditional Uyghur medicinal syndromes of malignant tumor. Chin J Integr Med 2011, 31:346-349.

15. Yin P: Serum metabolic profiling of abnormal savda by liquid chromatography/mass spectrometry. J Chromatogr B Analyt Technol Biomed Life Sci 2008, 871:322-327.

16. Christiansen L, Tan Q, lachina M, Bathum L, Kruse TA, McGue M, Christensen $\mathrm{K}$ : Candidate gene polymorphisms in the serotonergic pathway: influence on depression symptomatology in an elderly population. Biol Psychiatry 2007, 61(2):223-230.

17. Choi MJ, Kang RH, Ham BJ, Jeong HY, Lee MS: Serotonin receptor 2A gene polymorphism $(-1438 \mathrm{~A} / \mathrm{G})$ and short-term treatment response to citalopram. Neuropsychobiology 2005, 52(3):155-162.

18. Hong CJ, Chen TJ, Yu YW, Tsai SJ: Response to fluoxetine and serotonin $1 \mathrm{~A}$ receptor (C-1019G) polymorphism in Taiwan Chinese major depressive disorder. Pharmacogenomics J 2006, 6(1):27-33.

19. Kato M, Fukuda T, Wakeno M, Fukuda K, Okugawa G, Ikenaga Y, Yamashita M, Takekita Y, Nobuhara K, Azuma J, Kinoshita T: Effects of the serotonin type $2 \mathrm{~A}, 3 \mathrm{~A}$ and $3 \mathrm{~B}$ receptor and the serotonin transporter genes on paroxetine and fluvoxamine efficacy and adverse drug reactions in depressed Japanese patients. Neuropsychobiology 2006, 53(4):186-195

20. McMahon FJ, Buervenich S, Charney D, Lipsky R, Rush AJ, Wilson AF, Sorant AJ, Papanicolaou GJ, Laje G, Fava M, et al: Variation in the gene encoding the serotonin $2 \mathrm{~A}$ receptor is associated with outcome of antidepressant treatment. Am J Hum Genet 2006, 78(5):804-814.

21. Lemonde S, Turecki G, Bakish D, Du L, Hrdina PD, Bown CD, Sequeira A, Kushwaha N, Morris SJ, Basak A, et al: Impaired repression at a 5-hydroxytryptamine $1 \mathrm{~A}$ receptor gene polymorphism associated with major depression and suicide. J Neurosci 2003, 23(25):8788-8799.

22. Parsey RV, Oquendo MA, Ogden RT, Olvet DM, Simpson N, Huang YY, van Heertum RL, Arango V, Mann JJ: Altered serotonin 1A binding in major depression: a [carbonyl-C-11]WAY100635 positron emission tomography study. Biol Psychiatry 2006, 59(2):106-113.

23. Chao MV, Rajagopal R, Lee FS: Neurotrophin signalling in health and disease. Clin Sci (Lond) 2006, 110(2):167-173.

24. Duman RS: Role of neurotrophic factors in the etiology and treatment of mood disorders. Neuromolecular Med 2004, 5(1):11-25.

25. Yulug B, Ozan E, Kilic E: Brain-derived neurotrophic factor polymorphism as a genetic risk for depression? A short review of the literature. J Neuropsychiatry Clin Neurosci 2010, 22(1):123. E125-126.

26. Micheli D, Bonvicini C, Rocchi A, Ceravolo R, Mancuso M, Tognoni G, Gennarelli M, Siciliano G, Murri L: No evidence for allelic association of serotonin $2 \mathrm{~A}$ receptor and transporter gene polymorphisms with depression in Alzheimer disease. J Alzheimers Dis 2006, 10(4):371-378.

27. Cheng CY, Hong CJ, Yu YW, Chen TJ, Wu HC, Tsai SJ: Brain-derived neurotrophic factor (Val66Met) genetic polymorphism is associated with substance abuse in males. Brain Res Mol Brain Res 2005, 140(1-2):86-90.

28. Dinacci D, Tessitore A, Russo A, de Bonis ML, Lavorgna L, Picconi O, Sacco R, Bonavita S, Gallo A, Servillo G, et al: BDNF Val66Met polymorphism and brain volumes in multiple sclerosis. Neurol Sci 2011, 32(1):117-123.

29. Choi WS, Lee BH, Yang JC, Kim YK: Association Study between 5-HT1A Receptor Gene C(-1019)G Polymorphism and Panic Disorder in a Korean Population. Psychiatry Investig 2010, 7(2):141-146. 
30. Li D, Duan Y, He L: Association study of serotonin 2A receptor (5-HT2A) gene with schizophrenia and suicidal behavior using systematic meta-analysis. Biochem Biophys Res Commun 2006, 340(3):1006-1015.

31. Correa H, de Marco L, Boson W, Viana MM, Lima VF, Campi-Azevedo AC, Noronha JC, Guatimosim C, Romano-Silva MA: Analysis of T102C 5HT2A polymorphism in Brazilian psychiatric inpatients: relationship with suicidal behavior. Cell Mol Neurobiol 2002, 22(5-6):813-817.

32. Minov C, Baghai TC, Schule C, Zwanzger P, Schwarz MJ, Zill P, Rupprecht R, Bondy B: Serotonin-2A-receptor and -transporter polymorphisms: lack of association in patients with major depression. Neurosci Lett 2001, 303(2):119-122.

33. Ono H, Shirakawa O, Nishiguchi N, Nishimura A, Nushida $H$, Ueno $Y$, Maeda $\mathrm{K}$ : Serotonin $2 \mathrm{~A}$ receptor gene polymorphism is not associated with completed suicide. J Psychiatr Res 2001, 35(3):173-176.

34. Yoon HK, Yang JC, Lee HJ, Kim YK: The association between serotoninrelated gene polymorphisms and panic disorder. J Anxiety Disord 2008, 22(8):1529-1534.

35. Khait VD, Huang YY, Zalsman G, Oquendo MA, Brent DA, Harkavy-Friedman $\mathrm{JM}$, Mann JJ: Association of serotonin 5-HT2A receptor binding and the T102C polymorphism in depressed and healthy Caucasian subjects. Neuropsychopharmacology 2005, 30(1):166-172.

36. Duman RS, Monteggia LM: A neurotrophic model for stress-related mood disorders. Biol Psychiatry 2006, 59(12):1116-1127.

37. Kato M, Serretti A: Review and meta-analysis of antidepressant pharmacogenetic findings in major depressive disorder. Mol Psychiatry 2010, 15(5):473-500

38. Verhagen $M$, van der Meij A, van Deurzen PA, Janzing JG, Arias-Vasquez A Buitelaar JK, Franke B: Meta-analysis of the BDNF Val66Met polymorphism in major depressive disorder: effects of gender and ethnicity. Mol Psychiatry 2010, 15(3):260-271.

39. Chen L, Lawlor DA, Lewis SJ, Yuan W, Abdollahi MR, Timpson NJ, Day IN, Ebrahim S, Smith GD, Shugart YY: Genetic association study of BDNF in depression: finding from two cohort studies and a meta-analysis. Am J Med Genet B Neuropsychiatr Genet 2008, 147B(6):814-821.

40. Hwang JP, Tsai SJ, Hong CJ, Yang CH, Lirng JF, Yang YM: The Val66Met polymorphism of the brain-derived neurotrophic-factor gene is associated with geriatric depression. Neurobiol Aging 2006 27(12):1834-1837.

41. Jiang X, Xu K, Hoberman J, Tian F, Marko AJ, Waheed JF, Harris CR, Marini AM, Enoch MA, Lipsky RH: BDNF variation and mood disorders: a novel functional promoter polymorphism and Val66Met are associated with anxiety but have opposing effects. Neuropsychopharmacology 2005, 30(7):1353-1361.

42. Oswald P, Del-Favero J, Massat I, Souery D, Claes S, van Broeckhoven C, Mendlewicz J: No implication of brain-derived neurotrophic factor (BDNF) gene in unipolar affective disorder: evidence from Belgian first and replication patient-control studies. Eur Neuropsychopharmacol 2005, 15(5):491-495.

43. Schumacher J, Jamra RA, Becker T, Ohlraun S, Klopp N, Binder EB, Schulze TG, Deschner M, Schmal C, Hofels S, et al: Evidence for a relationship between genetic variants at the brain-derived neurotrophic factor (BDNF) locus and major depression. Biol Psychiatry 2005, 58(4):307-314.

44. Tsai SJ, Cheng CY, Yu YW, Chen TJ, Hong CJ: Association study of a brain-derived neurotrophic-factor genetic polymorphism and major depressive disorders, symptomatology, and antidepressant response. Am J Med Genet B Neuropsychiatr Genet 2003, 123B(1):19-22.

45. Shimizu E, Hashimoto K, lyo M: Ethnic difference of the BDNF 196G/A (val66met) polymorphism frequencies: the possibility to explain ethnic mental traits. Am J Med Genet B Neuropsychiatr Genet 2004, 126B(1):122-123

46. Pezawas L, Verchinski BA, Mattay VS, Callicott JH, Kolachana BS, Straub RE, Egan MF, Meyer-Lindenberg A, Weinberger DR: The brain-derived neurotrophic factor val66met polymorphism and variation in human cortical morphology. J Neurosci 2004, 24(45):10099-10102.

47. Szeszko PR, Lipsky R, Mentschel C, Robinson D, Gunduz-Bruce H, Sevy S, Ashtari M, Napolitano B, Bilder RM, Kane JM, et al: Brain-derived neurotrophic factor val66met polymorphism and volume of the hippocampal formation. Mol Psychiatry 2005, 10(7):631-636.
48. Huang EJ, Reichardt LF: Neurotrophins: roles in neuronal development and function. Annu Rev Neurosci 2001, 24:677-736.

49. Lu B, Pang PT, Woo NH: The yin and yang of neurotrophin action. Nat Rev Neurosci 2005, 6(8):603-614.

50. Anttila S, Huuhka K, Huuhka M, Rontu R, Hurme M, Leinonen E, Lehtimaki T: Interaction between 5-HT1A and BDNF genotypes increases the risk of treatment-resistant depression. J Neural Transm 2007, 114(8):1065-1068.

doi:10.1186/1472-6882-13-332

Cite this article as: Yusup et al:: Association study of gene polymorphisms and depression with abnormal humor in traditional Uighur medicine. BMC Complementary and Alternative Medicine 2013 13:332.

\section{Submit your next manuscript to BioMed Central and take full advantage of:}

- Convenient online submission

- Thorough peer review

- No space constraints or color figure charges

- Immediate publication on acceptance

- Inclusion in PubMed, CAS, Scopus and Google Scholar

- Research which is freely available for redistribution

Submit your manuscript at www.biomedcentral.com/submit
C Biomed Central 